\title{
Impact of half-sib family recurrent selection on grain yield in maize population ZM-309
}

Fawad Sheikh ${ }^{1}$, Amir Sohail ${ }^{2 *}$, Tanvir Burni ${ }^{3}$, Fazal Hadi ${ }^{3}$, Muhammad Asad ${ }^{3}$, Abdullah Aziz ${ }^{3}$, Abdul Haleem ${ }^{4}$, Mahrukh Maryam $^{1}$ and Zia Ur Rahman ${ }^{4}$

1. Department of Plant Breeding and Genetics, The University of Agriculture, Peshawar, Khyber PakhtunkhwaPakistan

2. State Key Laboratory of Rice Biology, China National Rice Research Institute, Hangzhou-China

3. Department of Botany, University of Peshawar Khyber Pakhtunkhwa-Pakistan

4. Oil Seed Directorate Sariab Quetta-Pakistan

*Corresponding author's email: amirsohail@aup.edu.pk

Citation

Fawad Sheikh, Amir Sohail, Tanvir Burni, Fazal Hadi, Muhammad Asad, Abdullah Aziz, Abdul Haleem, Mahrukh Maryam and Zia Ur Rahman. Impact of half-sib family recurrent selection on grain yield in maize population ZM-309. Pure and Applied Biology. Vol. 8, Issue 3, pp2399-2408.

http://dx.doi.org/10.19045/bspab.2019.80185

\begin{tabular}{|c|c|c|c|}
\hline Received: $10 / 05 / 2019$ & Revised: $14 / 07 / 2019$ & Accepted: 19/08/2019 & Online First: 07/09/2019 \\
\hline
\end{tabular}

\section{Abstract}

The prime objectives of maize breeding programs are to bring improvement in grain yield of maize. Recurrent selection is an important breeding technique for bringing desirable improvement in maize populations. The main objective of this investigation was to estimate genetic variability, heritability, selection differential, selection response and percent gain per cycle for various traits and also to assess the impact of half-sib family recurrent selection on grain yield in maize population ZM-309. Sixty-four half-sib families recurrently selected, and obtained from CIMMYT sourced maize population ZM-309, were tested in $8 \times 8$ partially balanced lattice square design in two replications at Cereal Crops Research Institute (CCRI), Pirsabak, Nowshera during 2018. Data were recorded on days to mid tasseling, plant height, ear height, ear length, grains rows per ear, hundred kernels weight and grain yield. Significant differences were observed among half-sib families for all the parameters. For days to $50 \%$ tasseling high heritability (0.83) was recorded, while the lowest heritability $(50 \%)$ was recorded for grain rows per ear. The response to selection was negative for days to tasseling (-2.44). Anthesis silking interval expressed highest genotypic covariance (56.44) while the lowest genotypic covariance was recorded for plant height (3.24). Highest percent gain per cycle was recorded for ear height (4.21\%) and plant height $(5.31 \%)$, while lowest percent gain per cycle was recorded for days to tasselling. Highest selection differential was observed for grain yield $(3.8 \%)$. After the completion of this experiment, it was deduced that enhancement in grain yield through half-sib family recurrent selection is useful and maize population ZM-309 can be exploited for further betterment through half-sib family recurrent selection.

Keywords: Half-sib recurrent family; Heritability; Percent gain per cycle; Selection differential;

Selection response

\section{Introduction}

Maize (Zea mays L.) is diploid specie of family Gramineae and due to its wider adaptability and high productivity. it is a widely grown crop in most parts of the world [1]. It is an annual, short day, cross- 
pollinated crop and due to its short cropping duration it can be cultivated in spring and summer seasons in Pakistan. Due to highly allogamous nature it does not survive in wild form. From nutrition point of view, maize is composed of $66.8 \%$ starch, $9.9 \%$ protein, $4.7 \%$ oil, $8.6 \%$ fiber, $3 \%$ suger, and $7.1 \%$ ash [2]. Industrially maize can be used for development of starch, tanning material, alcohol, oil and polishes, etc. at significant level [3]. Maize is one of the potential crops in most of the developing countries for fulfilling of the requirements of increasing population as it can be cultivated in temperate, tropical and subtropical countries of the world. It can be grown from $500 \mathrm{~N}$ to $400 \mathrm{~S}$ in latitude and up to $3300 \mathrm{~m}$ in altitude of above the sea level [4].

Globally maize produces 786 million metric tons from an area of more than 118.2 million hectares. In Pakistan, maize is the largest grown crop after wheat, cotton and rice and is grown 1131 thousand hectares with 4.699 million tons of grain and average grain yield of about $4053 \mathrm{~kg} / \mathrm{ha}$ [5]. Out of the total cereal cropped area in Pakistan, maize accounts for 8.5 percent, while 2.2 percent to the value added in agriculture and 0.4 percent to GDP. Apart from domestic use, maize cultivation plays an important economic role by employing its value adding chain [6]. Due to high grain yield potential and productivity maize can be phenomenal in reducing and eradicating hunger from third world countries.

Identification of superior genotypes in a mixed or base population is one of the significant aims of plant breeders [7]. There are different methods of selection in maize such as modified ear to row selection, mass selection, recurrent selection, half-sib and full-sib family recurrent selection. Maize breeders most commonly used these methods for bringing improvement and stability in yield. The prime purpose of recurrent selection to increase the frequency of favourable genes for characters (like yield, oil content, etc.) by repeated cycles of selection. For bringing desire able improvement in maize yield, scientists prefer recurrent selection procedure. Recurrent selection is reselection generation after generation, with the interbreeding of selects to provide for genetic recombination. To improve the cross between two populations by exploiting both additive and non-additive genetic effects, the reciprocal recurrent selection was initially been proposed by [8] Improvement of the cross by complementary improvement in two parental populations is a logical approach for maize breeding programs in which hybrids are the ultimate goal [9].

Half-sib individuals are those individuals having only one parent in common i.e. one parent is known while the other one is unknown. In recurrent half-sib selection intra-population enhancement is brought through the evaluation of the half-sib progeny. The earliest form of half-sib recurrent selection was an ear to row selection as a method of altering the chemical composition of maize. For reducing inbreeding depression in maize populations HSF re-selection is extremely effectual [10].

Heritability is the proportionate genetic and phenotypic variance. It is denoted by " $\mathrm{h}$ ". Its value ranges from 0 to 1 or $0 \%$ to $100 \%$ whereas the diversity of base population means from the mean of the selected individuals is called as selection differential. Selection differential is the amount of gain attained through selection [11].

Currently ZM-309 is under improvement at CCRI, Nowshera for its possible introduction in Khyber Pakhtunkhwa specifically and Pakistan generally. Looking at the significance and ability of half-sib family re- selection in maize, the experiment was conducted with objectives to produce half-sib families from selected lines through recurrent selection in maize population ZM-309. To estimate the genetic components of variance and heritability, and to determine selection response and selection differential after one 
cycle of HSF recurrent selection in maize population ZM-309.

\section{Materials and methods}

The procedure, material, and methods used in the present study were as follow.

\section{Location and Breeding material}

This experiment was conducted at Cereal Crops Research Institute (CCRI) Pirsabak, Nowshera in spring and summer season 2018. Breeding material comprising halfsib (HS) families were developed from CIMMYT sourced population as base population $\mathrm{C}_{1}$ and then $\mathrm{C}_{2}$ was evaluated in Kharif season (2018).

\section{Procedure and field experiment}

The farm was regularly visited to discard the undesired plants. About 75-80finest cobs were selected from half-sib families based on ear length, grains per cob, grain size, grain setting and free from a disease which was then followed by recurrent selection. The HS lines were pollinated manually by the bulked male lines. Plants were hand-harvested at physiological maturity. Half-sib lines with maximum grain filling, ear length, and good-looking cobs were selected. During the summer 2018, half-sib lines, along with one check, were evaluated in a replicated trial using a partially balanced lattice square design with two replications. Row length was kept at 5 $\mathrm{m}$, with $0.25-\mathrm{m}$ plant-to-plant spacing and 0.75-m row-to-row spacing. Standard cultural practices were carried out in both seasons. Fertilizer was applied in the form of di ammonium phosphate and urea at the rate of 125 and $250 \mathrm{~kg} / \mathrm{ha}$, respectively. The crop was irrigated weekly.

Data was recorded for days to tasselling, plant height $(\mathrm{cm})$, ear height $(\mathrm{cm})$, ear length $(\mathrm{cm})$, grain rows $\mathrm{cob}^{-1}$, hundredgrain weight (g) and Grain yield; Grain yield was calculated in $\mathrm{kg} \mathrm{ha}^{-1}$ by using the following formula:

\section{Grain yield $\left(\mathrm{kg} \mathrm{ha}^{-1}\right)=\underline{\text { FEW }\left(\mathrm{kg} \mathrm{plot}^{-1}\right) \times(100-\mathrm{MC}) \times 0.8 \times 10,000}$ $(100-15) \times$ Area harvested}

Where,

$\mathrm{S}=0.8$

$\mathrm{FEW}=$ fresh ear weight at harvest in $\mathrm{kg} \mathrm{plot}^{-}$

100-15 = Required grain moisture for storage

\section{Statistical analysis}

All the observed data were subjected to an appropriate lattice square design recommended by [12]. All characters were matched with the local check and among the half-sib families.

\section{Estimation of heritability}

Genetic variance and environmental variance of the traits mentioned above were computed from mean squares.

Genetic variance $\left(\sigma^{2} \mathrm{~g}\right)=\mathrm{M}_{1}-\mathrm{M}_{2} / \mathrm{r}$ Phenotypic Variance $\left(\sigma^{2} \mathrm{p}\right)=\sigma^{2} \mathrm{~g}+\sigma^{2} \mathrm{e}$ Heritability $\left(\mathrm{h}_{\mathrm{bs}}^{2}\right)=\sigma^{2} \mathrm{~g} / \sigma^{2} \mathrm{p}$ $\mathrm{M}_{1}=$ Genetic mean squares from the analysis of variance (ANOVA)

$\mathrm{M}_{2}=$ Error mean squares from ANOVA $\mathrm{r}=$ number of replications

\section{Selection differential (S)}

The formula used for calculating selection differential is given

Selection differential $(\mathrm{S})=\mu \mathrm{HS}-\mu$

Where

$\mu=$ population mean of HS families

$\mu \mathrm{HS}=$ mean of selected HS families

\section{Expected response}

The formula used for calculating the expected response is given as

$\mathrm{Re}=\mathrm{S} \times \mathrm{h}^{2}$

\section{Percent gain per cycle}

Percent gain per cycle was calculated according to the formula given by [3].

Gain per cycle $(\%)=$ Cycle $_{2}-$ Cycle $_{1} \times 100$

$$
\text { Cycle }_{1}
$$

Genotypic and Environmental CV (\%)

A genotypic and environmental CV (\%) was calculated according to the formula given by [13].

$\mathrm{ECV}=\sigma \mathrm{E} / \mathrm{y} \times 100$

$\mathrm{GCV}=\sigma \mathrm{G} / \mathrm{y} \times 100$

Index of variation (IV)

Index of variation was calculated by using the formula given as 
$\mathrm{I} . \mathrm{V}=\mathrm{GCV} / \mathrm{ECV}$

\section{Results and discussion}

From CIMMYT sourced base population ZM-309 maize half-sib families were derived and studied at CCRI, Nowshera, Pakistan during spring and Kharif season 2018. Data was taken on various parameters related to grain yield and morphology.

\section{Days to 50\% tasseling}

Mean square value for days to tasseling extremely considerable differences were observed among half-sib families, (Table 1) while the coefficient of variation was 1.89 $\%$. Among the tested families of $\mathrm{C}_{1}$ and $\mathrm{C}_{2}$ means values were 50 and 47, respectively for days to $50 \%$ tasselling (Table 2). For selected half-sib families of $\mathrm{C}_{2}$ mean value was 50 . The witnessed increase per cycle was -0.83 , after one the cycle of selection for days to tasselling (Table 3). The highest heritability value of 0.83 was observed for the said trait amongst the half-sib families after second cycle of selection. For days to male flowering, high genetic variance of 4.45 was observed as compared to environmental variance with heritability value of 0.83 (Table 4). According to the heritability estimation and selection differential the projected response to selection for days to tasseling was 2.44, GCV and ECV were 4.21 and 1.89, respectively (Table 5). Significant differences were reported among full-sib families of different maize varieties for different traits by [14]. For days to significant tasselling, differences in half-sib families of maize were also reported by [15]. The overall maturity of the crop is reduced due to a reduction in physiological maturity, the crop can be saved from all the threats whether biotic or abiotic. A population developed from maize variety Sarhad White also noted a significant difference for days to tasselling [16].

\section{Plant height}

The differences observed were highly significant among all the half-sib families for mean square values of plant height, while the coefficient of variation was $1.67 \%$ (Table 1 ). The observed genetic gain per cycle was $4.41 \%$ after one selection cycle, for plant height (Table 3). For plant height high genetic variance of 26.99 was observed as compared to the environmental variance of 7.08 with heritability value of 0.79 (Table 4). From the approximation of heritability and selection differential, the projected response to selection for plant height was $0.08 \%$. Genetic and environmental coefficients were 3.24 and 1.66 , respectively (Table 5). Plant height is one of the most important agronomic traits in maize which plays a vital role in lodging and hence affect the grain yield. High heritability value was also reported for plant height by [17]. Same results were also obtained by [17], who observed significant differences among $S_{1}$ lines of Azam maize variety.

\section{Ear height}

The differences observed were vastly considerable among all the half-sib families for mean square values for ear height, while the coefficient of variation was $5.83 \%$ (Table $1 \& 2$ ). The observed percent genetic gain per cycle was $5.31 \%$ after one selection cycle for ear height. From the estimates of selection differential, the predicted response to selection for ear height was $1.31 \%$ (Table 3 ). High estimates of heritability were observed for the said trait among the half-sib families after the first cycle of selection. For ear height high genetic variance of 32.72 was observed as compared to environmental variance of 18.24 with heritability value of 0.64 (Table 4). Genetic and the environmental coefficients were 7.81 and 5.83, respectively (Table 5). The same findings were also observed by [18], who also recorded significant differences in plant and ear height of ESLAQ-PB variety. Significant results for ear height and plant height in two maize populations in the Northeast of Spain were also reported by [19].

\section{Ear length}

The differences observed were extremely considerable among all the half-sib families for mean square values for ear length, while 
the coefficient of variation was $4.12 \%$ (Table $1 \& 2$ ). The observed percent genetic gain per cycle was 5.40after one selection cycle for ear length (Table 3). Moderate values of heritability were observed for the said trait amongst the half-sib families after the first cycle of selection. For ear length genetic variance of 0.53 was observed while environmental variance was 0.43 with heritability value of 0.54 (Table 4). From estimates of heritability and selection differential the projected response to selection for ear length was 0.01 (Table 3). The proportion of genetic coefficient of variation and environmental coefficient of variation was 6.15 while the genetic and environmental coefficients were 4.55 and 4.12, respectively (Table 5). Ear length is an important parameter contributing directly to the final grain yield and is of prime importance. Similar results were also obtained by [20], who studied the change in heritability estimates due to half-sib family selection in the maize variety Paharhi.

\section{Grain rows ear ${ }^{-1}$}

The differences observed were highly significant among all the half-sib families for mean square values for kernel rows per ear (Table $1 \& 2$ ) whereas CV was $5.35 \%$. The observed percent genetic gain per cycle was 1.37 after one selection cycle for kernel rows ear $^{-1}$ (Table 3 ). Heritability observed was moderate for the said trait amid the half-sib families after the first cycle of selection (Table 4). For kernel rows ear-1 0.45 genetic variance was observed while environmental variance was also 0.45 with heritability value of 0.50 .From the estimates of heritability and selection differential the expected response to selection for kernel rows ear $^{-1}$ was $0.23 \%$ (Table 3). The proportion of genetic and environmental coefficient of variation was $7.57 \%$ while genetic and environmental coefficients were $5.35 \%$ (Table 5). Kernel rows ear $^{-1}$ is an important parameter contributing to grain yield. Ear diameter and grain rows per ear are critical components in maize grain yield. Highly significant differences were observed for grain yield which was also recorded by [16], who also observed high values of heritability for kernel rows per cob, kernels per row and ear height while studying 146 HS- families derived from maize population Sarhad white.

\section{0-grains weight}

The differences observed were highly significant among all the half-sib families for mean square values for100 grains weight (Table $1 \& 2$ ) while the coefficient of variation was $6.41 \%$. The observed percent genetic gain per cycle was $36.5 \%$ after one selection cycle for 100 grains weight (Table 3). Heritability values observed were moderate for the said trait among the half-sib families after cycle of selection. For 100-grains weight genetic variance was 10.62 as compared to environmental variance of 6.41 with heritability value of 0.62 (Table 4). From the estimates of heritability and selection differential, the expected response to selection for 100 grains weight was 0.38 (Table 3). The proportion of genetic and environmental coefficient of variation was $8.25 \%$ and $6.41 \%$, respectively (Table 5 ). [16] Assessed grain yield connected traits in maize and recorded significant variation for all the traits. Positive and high selection differential values for earliness and yield, in two cycles in maize progeny selection was also reported by [21].

\section{Grain yield}

The differences observed were highly significant among all the half-sib families for mean square values for grain yield (Table $1 \& 2$ ) while the coefficient of variation was $15.82 \%$. The observed percent genetic gain per cycle was $5.14 \%$, after first selection cycle for grain yield (Table 3). Heritability values observed were moderate for the said trait among the half-sib families after the first cycle of selection. For grain yield high genetic variance of 858051.54 was observed as compared to the environmental variance of 713699.80 , with heritability value of 0.50 (Table 4). From the estimates of heritability and selection differential the predicted 
response to selection for grain yield was $2.8 \%$ (Table 5). Genetic coefficient of variation and environmental coefficients was 17.55 and $14.82 \%$, respectively while the proportion of genetic and environmental coefficient of variation was $23.48 \%$ (Table 5). Our conclusions are in line with the findings of [22], who observed medium to maximum heritability values for almost all the traits in both cycles. They got positive and high selection differential values for prolificacy, ear length, grain yield, ear height, and 100-grain weight in two cycles. [16] Investigated half-sib families at Cereal Crop Research Institute and also recorded high heritability (0.74) for grain yield in $\mathrm{C}_{0}$, while moderate heritability (0.45) was recorded for kernel rows ear ${ }^{-1}$ in $C_{1}$.

Table 1. Mean squares for families and error and variations coefficient for all the flowering and yield related parameters of HSF of maize ZM-309

\begin{tabular}{|c|c|c|c|}
\hline \multirow{2}{*}{ Traits } & \multicolumn{2}{|c|}{ Mean squares } & \multirow{2}{*}{ CV (\%) } \\
\cline { 2 - 3 } & Families & Error & \\
\hline Days to tasseling & $9.80^{* *}$ & 0.90 & 1.89 \\
\hline Plant height $(\mathrm{cm})$ & $8.6^{* *}$ & 7.08 & 1.66 \\
\hline Ear height $(\mathrm{cm})$ & $83.67^{* *}$ & 18.27 & 5.83 \\
\hline Ear length $(\mathrm{cm})$ & $1.48^{* *}$ & 0.43 & 4.12 \\
\hline Ear diameter $(\mathrm{cm})$ & $0.18^{* *}$ & 0.04 & 4.85 \\
\hline Grain rows ear ${ }^{-1}$ & $1.34^{* *}$ & 0.45 & 5.35 \\
\hline 100 -grain weight $(\mathrm{g})$ & $27.64^{* *}$ & 6.41 & 6.41 \\
\hline Grain yield $\left(\mathrm{kgha}^{-1}\right)$ & $2429802.88^{* *}$ & 713699.80 & 15.82 \\
\hline
\end{tabular}

** = Significance level of probability at $1 \%$

Table 2. Mean values for days to tasseling, plant height, ear height, cob length, cob diameter, grains per row, 100grain weight, grain rows per ear, grain yield of the half-sib families derived from maize population ZM-309

\begin{tabular}{|c|c|c|c|c|c|c|c|}
\hline Half-sib families & DTT & $\begin{array}{c}\text { PH } \\
(\mathbf{c m})\end{array}$ & $\mathbf{E H}(\mathbf{c m})$ & $\mathbf{E L}(\mathbf{c m})$ & GRPE & $\mathbf{1 0 0 - G W}$ & GY \\
\hline ZM309-C2-HSF-1 & 48 & 138.333 & 74.1667 & 16.3 & 11.3 & 40.0 & 4793.7 \\
\hline ZM309-C2-HSF-2 & 47 & 112.5 & 65.0 & 16.5 & 12.0 & 42.0 & 5609.4 \\
\hline ZM309-C2-HSF-3 & 46 & 135 & 62.5 & 16.6 & 12.0 & 38.5 & 6450.2 \\
\hline ZM309-C2-HSF-4 & 46 & 137.5 & 63.3 & 16.7 & 12.7 & 37.5 & 6677.3 \\
\hline ZM309-C2-HSF-5 & 47 & 124.167 & 56.7 & 16.7 & 12.7 & 38.5 & 4818.8 \\
\hline ZM309-C2-HSF-6 & 48 & 140.833 & 74.2 & 15.2 & 12.3 & 42.0 & 5546.7 \\
\hline ZM309-C2-HSF-7 & 46 & 125.833 & 59.2 & 14.6 & 12.0 & 32.0 & 3827.5 \\
\hline ZM309-C2-HSF-8 & 45 & 128.333 & 48.3 & 14.6 & 11.7 & 35.0 & 5647.1 \\
\hline ZM309-C2-HSF-9 & 47 & 135 & 66.7 & 16.8 & 13.0 & 36.0 & 4680.8 \\
\hline ZM309-C2-HSF-10 & 49 & 132.5 & 66.7 & 15.5 & 12.3 & 34.5 & 4611.8 \\
\hline ZM309-C2-HSF-11 & 48 & 124.167 & 56.7 & 15.2 & 12.7 & 32.5 & 4643.1 \\
\hline ZM309-C2-HSF-12 & 46 & 131.667 & 70.0 & 16.2 & 11.7 & 37.5 & 5691.0 \\
\hline ZM309-C2-HSF-13 & 48 & 128.333 & 66.7 & 14.9 & 12.3 & 37.5 & 5276.9 \\
\hline ZM309-C2-HSF-14 & 49 & 117.5 & 56.7 & 15.8 & 12.0 & 37.0 & 5722.4 \\
\hline
\end{tabular}




\begin{tabular}{|c|c|c|c|c|c|c|c|}
\hline ZM309-C2-HSF-15 & 48 & 133.333 & 71.7 & 15.3 & 12.7 & 31.5 & 5283.1 \\
\hline ZM309-C2-HSF-16 & 47 & 129.167 & 60.8 & 15.9 & 11.7 & 37.0 & 6236.9 \\
\hline ZM309-C2-HSF-17 & 49 & 123.333 & 65.8 & 14.8 & 12.7 & 39.5 & 4731.0 \\
\hline ZM309-C2-HSF-18 & 48 & 115.833 & 52.5 & 15.1 & 12.7 & 37.5 & 5195.3 \\
\hline ZM309-C2-HSF-19 & 48 & 125.833 & 63.3 & 15.1 & 12.0 & 40.5 & 4761.1 \\
\hline ZM309-C2-HSF-20 & 45 & 110 & 55.0 & 15.3 & 12.0 & 36.5 & 5142.6 \\
\hline ZM309-C2-HSF-21 & 46 & 123.333 & 61.7 & 15.7 & 12.0 & 40.0 & 4191.4 \\
\hline ZM309-C2-HSF-22 & 47 & 116.667 & 55.0 & 15.1 & 12.7 & 41.0 & 4216.5 \\
\hline ZM309-C2-HSF-23 & 48 & 124.167 & 61.7 & 16.0 & 12.7 & 39.5 & 5151.4 \\
\hline ZM309-C2-HSF-24 & 48 & 126.667 & 56.7 & 17.5 & 12.3 & 40.5 & 3764.7 \\
\hline ZM309-C2-HSF-25 & 49 & 115 & 55.0 & 15.5 & 13.7 & 38.5 & 4185.1 \\
\hline ZM309-C2-HSF-26 & 47 & 127.5 & 69.2 & 16.3 & 11.7 & 39.5 & 5578.0 \\
\hline ZM309-C2-HSF-27 & 49 & 133.333 & 59.2 & 16.2 & 12.3 & 38.5 & 6632.2 \\
\hline ZM309-C2-HSF-28 & 45 & 123.333 & 68.3 & 15.9 & 12.7 & 38.0 & 5747.5 \\
\hline ZM309-C2-HSF-29 & 48 & 128.333 & 57.5 & 14.6 & 12.0 & 37.0 & 4705.9 \\
\hline ZM309-C2-HSF-30 & 47 & 132.5 & 65.0 & 17.4 & 12.7 & 39.0 & 6174.1 \\
\hline ZM309-C2-HSF-31 & 49 & 123.333 & 55.8 & 16.3 & 13.0 & 37.5 & 5113.7 \\
\hline ZM309-C2-HSF-32 & 49 & 116.667 & 60.0 & 16.5 & 12.0 & 38.0 & 5647.1 \\
\hline ZM309-C2-HSF-33 & 46 & 299.167 & 62.5 & 16.0 & 12.3 & 38.0 & 5220.4 \\
\hline ZM309-C2-HSF-34 & 46 & 142.5 & 65.0 & 16.5 & 13.0 & 40.0 & 5722.4 \\
\hline ZM309-C2-HSF-35 & 48 & 129.167 & 66.7 & 14.9 & 12.3 & 41.5 & 4210.2 \\
\hline ZM309-C2-HSF-36 & 48 & 127.5 & 77.5 & 15.8 & 12.3 & 40.0 & 5176.5 \\
\hline ZM309-C2-HSF-37 & 46 & 133.333 & 59.2 & 15.5 & 12.0 & 40.5 & 6575.7 \\
\hline ZM309-C2-HSF-38 & 47 & 127.5 & 60.8 & 16.0 & 12.0 & 41.0 & 5716.1 \\
\hline ZM309-C2-HSF-39 & 46 & 124.167 & 67.5 & 16.4 & 12.0 & 38.0 & 4668.2 \\
\hline ZM309-C2-HSF-40 & 48 & 130 & 60.8 & 15.8 & 12.3 & 34.5 & 3739.6 \\
\hline ZM309-C2-HSF-41 & 45 & 130.833 & 56.7 & 16.0 & 12.0 & 43.5 & 5797.7 \\
\hline ZM309-C2-HSF-42 & 45 & 120 & 56.7 & 16.1 & 12.3 & 37.5 & 4272.9 \\
\hline ZM309-C2-HSF-43 & 46 & 117.5 & 55.8 & 15.6 & 12.7 & 40.0 & 4718.4 \\
\hline ZM309-C2-HSF-44 & 48 & 119.167 & 58.3 & 15.7 & 12.0 & 35.0 & 5170.2 \\
\hline ZM309-C2-HSF-45 & 49 & 128.333 & 61.7 & 16.2 & 12.7 & 33.2 & 4655.7 \\
\hline ZM309-C2-HSF-46 & 47 & 137.5 & 58.3 & 14.7 & 12.7 & 34.0 & 2793.4 \\
\hline ZM309-C2-HSF-47 & 48 & 124.183 & 60.8 & 16.5 & 11.7 & 35.0 & 5145.1 \\
\hline ZM309-C2-HSF-48 & 47 & 122.5 & 55.8 & 16.3 & 11.7 & 36.0 & 4774.9 \\
\hline ZM309-C2-HSF-49 & 46 & 121.667 & 58.3 & 16.2 & 11.7 & 40.0 & 4335.7 \\
\hline ZM309-C2-HSF-50 & 48 & 126.667 & 67.5 & 14.3 & 12.0 & 37.0 & 4894.1 \\
\hline ZM309-C2-HSF-51 & 46 & 117.5 & 59.2 & 15.1 & 13.0 & 36.5 & 3708.2 \\
\hline ZM309-C2-HSF-52 & 47 & 121.667 & 55.0 & 15.3 & 11.7 & 36.0 & 5258.0 \\
\hline ZM309-C2-HSF-53 & 48 & 134.167 & 57.5 & 15.3 & 12.7 & 40.0 & 3714.5 \\
\hline ZM309-C2-HSF-54 & 46 & 121.667 & 63.3 & 16.5 & 12.0 & 40.0 & 6117.7 \\
\hline ZM309-C2-HSF-55 & 48 & 123.333 & 54.2 & 15.4 & 12.3 & 32.5 & 4323.1 \\
\hline
\end{tabular}




\begin{tabular}{|c|c|c|c|c|c|c|c|}
\hline ZM309-C2-HSF-56 & 47 & 115 & 64.2 & 15.8 & 12.3 & 36.0 & 4768.6 \\
\hline ZM309-C2-HSF-57 & 46 & 141.667 & 67.5 & 15.4 & 12.3 & 33.5 & 3752.2 \\
\hline ZM309-C2-HSF-58 & 49 & 120 & 60.0 & 17.4 & 12.3 & 35.5 & 5571.8 \\
\hline ZM309-C2-HSF-59 & 47 & 133.333 & 64.2 & 15.9 & 11.7 & 38.5 & 4310.6 \\
\hline ZM309-C2-HSF-60 & 46 & 124.167 & 59.2 & 16.1 & 12.3 & 38.0 & 4806.3 \\
\hline ZM309-C2-HSF-61 & 48 & 116.667 & 61.7 & 16.5 & 12.7 & 38.5 & 6174.1 \\
\hline ZM309-C2-HSF-62 & 47 & 121.667 & 57.5 & 15.8 & 12.0 & 37.5 & 3708.2 \\
\hline ZM309-C2-HSF-63 & 48 & 132.5 & 61.7 & 15.3 & 13.0 & 36.5 & 5101.2 \\
\hline ZM309-C1 & 48 & 118.667 & 61.7 & 14.0 & 12.0 & 35.0 & 6763.9 \\
\hline
\end{tabular}

Table 3. Means $(\mu)$ of the base population $\left(\mathrm{C}_{0}\right)$, HSF $\left(\mathrm{C}_{1}\right)$, selected HSF mean $(\mu \mathrm{HS})$, expected response (Re), Selection differential $(S)$ and per cent gain cycle $^{-1}$ for flowering and yield-related parameters of the HSF derived from maize population ZM-309

\begin{tabular}{|c|c|c|c|c|c|c|}
\hline Parameters & $\mathrm{C}_{0} \mu$ & $\mathbf{C}_{1} \mu$ & $\mu \mathbf{H S}$ & $\mathbf{S}$ & $\operatorname{Re}$ & 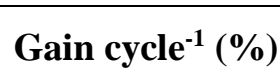 \\
\hline Days to tasseling & 50.50 & 50.08 & 47 & -2.93 & -2.44 & -0.83 \\
\hline Plant height $(\mathrm{cm})$ & 167 & 160 & 159 & -0.10 & -0.08 & -4.41 \\
\hline Ear height $(\mathrm{cm})$ & 75 & 73 & 69 & -2.05 & -1.31 & -5.31 \\
\hline Ear length $(\mathrm{cm})$ & 15.03 & 15.6 & 18 & 0.95 & 0.9 & 1.40 \\
\hline Ear diameter $(\mathrm{cm})$ & 2.20 & 2.30 & 2.65 & 0.03 & 0.02 & 2.97 \\
\hline Grain rows ear ${ }^{-1}$ & 13.70 & 14.50 & 16.0 & 0.46 & 0.23 & 1.37 \\
\hline 100-grain weight (g) & 41.50 & 43.50 & 46.98 & 0.61 & 0.38 & 3.75 \\
\hline Grain yield $\left(\mathrm{kgha}^{-1}\right)$ & 3185.36 & 3410.25 & 3555.20 & 3.8 & 2.89 & 5.14 \\
\hline
\end{tabular}

Table 4. Environmental variances $\left(V_{E}\right)$, genetic variance $\left(V_{G}\right)$, phenotypic variances $\left(V_{P}\right)$, and heritability $\left(h_{b . s}\right)$ for flowering and yield related parameters of the HSF developed from maize population ZM-309

\begin{tabular}{|c|c|c|c|c|}
\hline Traits & $\mathbf{V}_{\mathbf{G}}$ & $\mathbf{V}_{\mathbf{E}}$ & $\mathbf{V}_{\mathbf{P}}$ & $\mathbf{h}^{2}$ \\
\hline Days to tasseling & 4.45 & 0.90 & 5.35 & 0.83 \\
\hline Plant height $(\mathrm{cm})$ & 26.99 & 7.08 & 34.07 & 0.79 \\
\hline Ear height $(\mathrm{cm})$ & 32.72 & 18.24 & 50.96 & 0.64 \\
\hline Ear length $(\mathrm{cm})$ & 0.53 & 0.43 & 0.96 & 0.55 \\
\hline Ear diameter $(\mathrm{cm})$ & 0.07 & 0.04 & 0.11 & 0.63 \\
\hline Grain rows ear ${ }^{-1}$ & 0.45 & 0.45 & 0.89 & 0.50 \\
\hline 100-grain weight (g) & 10.62 & 6.41 & 17.03 & 0.62 \\
\hline Grain yield $\left(\mathrm{kgha}^{-1}\right)$ & 858051.54 & 713699.80 & 1571751.34 & 0.55 \\
\hline
\end{tabular}


Table 5. Genotypic coefficient of variation and variation index for flowering and yield attributing parameters of the half-sib families from maize population ZM-309

\begin{tabular}{|c|c|c|c|}
\hline Traits & GCV (\%) & PCV (\%) & I.V \\
\hline Days to tasseling & 4.21 & 4.62 & 2.22 \\
\hline Plant height $(\mathrm{cm})$ & 3.24 & 3.65 & 1.95 \\
\hline Ear height $(\mathrm{cm})$ & 7.81 & 9.75 & 1.34 \\
\hline Ear length $(\mathrm{cm})$ & 4.55 & 6.14 & 1.10 \\
\hline Ear diameter $(\mathrm{cm})$ & 6.29 & 7.94 & 1.30 \\
\hline Grain rows ear ${ }^{-1}$ & 5.35 & 7.57 & 1.00 \\
\hline 100 -grain weight $(\mathrm{g})$ & 8.25 & 10.45 & 1.29 \\
\hline Grain yield $\left(\mathrm{kgha}^{-1}\right)$ & 17.35 & 23.48 & 1.10 \\
\hline
\end{tabular}

\section{Conclusion and recommendations}

From the findings of this experiment it was deduced that half-sib family recurrent selection in maize is an effective method and maize population ZM-309 has the potential to be used in future breeding programs. Minimum days to tasseling were recorded for 37, 54 and 27 families. Maximum mean values were recorded for ear length, and grain yield for family 24 and family 58 and has the potential to be used in future breeding programs. Negative values of selection response and gain cycle ${ }^{-1}$ were recorded for days to silking, anthesis and tasseling, while for yield and yield attributing parameters positive values of selection response and gain cycle $^{-1}$ were recorded. The enhancement in grain yield through half-sib family recurrent selection is useful and maize population ZM-309 can be exploited for further betterment through half-sib family recurrent selection.

\section{Authors' contributions}

Conceived and designed the experiments: $\mathrm{F}$ Sheikh, Performed the experiments: F Sheikh, Analyzed the data: A Sohail, H Shulei, A Haleem, M Maryam \& M Aasd, Contributed reagents/ materials/ analysis tools: T Burni, F Hadi \& A Aziz, Wrote the paper: A Sohail.

\section{References}

1. Sohail A, Rahman H, Khan MY, Burni $\mathrm{T}$, Shah SMA, Naz R \& Manzoor
(2018). Estimation of genetic variability, heritability, index of variation and correlation in the half-sib families of CIMMYT maize population CZP-132011. Pure Appl Biol 7(1): 365-373.

2. Sohail A, Hussain Q, Ali S, Manzoor, Hadi F, Uddin S, Bashir F, Asad M, Sami S \& Yousafzai Z (2018). Evidence of improving yield and yield attributes via half-sib family recurrent selection in maize (Zea mays L.). Int $J$ Curr Res Biosci Pl Biol 5(12), 45-56.

3. Fehr WR (1987). Principles of cultivar development.1, 351-353. Macmillan Publish. Co. New York.

4. Singh G, Kumar R \& Jasmine (2017). Genetic parameters and character association study for yield traits in maize (Zea mays L.). Journal of Pharmacognosy and Phytochemistry 6(5): 808-813.

5. MINFAL (2017). Govt. of Pakistan, Ministry of Food Agriculture and Livestock. Economics Wing, Islamabad, pp16-21 (2017).

6. FAO (2017). Food and Agricultural Organization of the United Nations 2015. http:// faostat3. fao.org/ faostatgateway/go/to/download/Q/QC/ E. Accessed on 28 March. 2017.

7. Khan A (2017). Performance of full sib families in different maize varieties for 
morphological characters. Annals Agrarian Sci 15: 113-117.

8. Cunha KS, Pereira1 MG, Gonçalves LSA, Berilli APCG, Oliveira EC, Ramos HCC \& Junior ATA (2012). Full-sib reciprocal recurrent selection in the maize populations CIMMYT and Piranao. Genet Mol Res 11(3): 33983408.

9. Hallauer AR \& MJ Carena (2012). Recurrent selection methods to improve germplasm in maize. Maydica 57: 266-283.

10. Smith OS, Hallauer AR \& Russell WA (2011). Use of index selection in recurrent Selection programs in maize. Euphytica 30: 611-618.

11. Ogunniyan DJ \& Olakojo SA (2014). Genetic variation, heritability, genetic advance and agronomic character association of yellow elite inbred lines of maize (Zea mays L.). Nigerian $J$ Genet 28: 24-28.

12. Milles JW, Dudley JW, White DG \& Lambert RJ (1980). Improving corn population for grain yield and resistance to leaf blight and stalk rot. Crop Sci 20: 247-250.

13. Johnson HW, Robinson HF and Comstock RE (1955). Estimation of genetic and environmental variability in soybeans. Agron J 47: 314-318.

14. Sohail A, Rahman H, Hussain Q, Hadi F, Ullah U, Khan W, Khan MA, Asad M, Yousafzai Z, Sami S \& Uddin S. (2018). Genetic variability, heritability and correlation studies in half-sib recurrent families of CIMMYT maize population CZP-132011. ARPN $J$ Agric Boil Sci 13(10): 1-7.

15. Noor M, Shahwar D, Rahman H, Ullah H, Ali F, Iqbal M, Shah IA \& Ullah I 2013. Change in heritability estimates due to half-sib family selection in the maize variety Pahari. Genet Mol Res 12(2): 1872-1881.
16. Ishaq M, Hassan $\mathrm{G}$, Rahman $\mathrm{H}$, Iqbal M, Khalil IA, Khan SA, Khan SA, Rafiullah \& Hussain J (2014). Estimates of heritability and expected response for maturity and grain yield related traits in half-sib recurrent families of maize. Pak J Biotech 12(2): 141-151.

17. Mahmood Z, Malik SR, Akhtar R \& Rafique $T$ (2004). Heritability and genetic advance estimates from maize genotypes in Shishi Lusht a valley of Krakurm. Inter J Agric Bio 6(5): 790791.

18. Khalil IA, Rahman HU, Hahwar D, Nawaz I, Ullah H \& Ali F (2010). Response to selection for grain yield under maydis leaf blight stress environment in maize (Zea mays L.). Biol Diversity Cons 3(1): 121-127.

19. Andrade JADC \& Filho JBDM (2008). Quantitative variation in the tropical maize population, ESALQ-PB1. Sci Agric 65(2): 174-182.

20. Noor M, Rahman H, Iqbal M, Shah IA, Ihteramullah, Durrishawar \& Ali F (2013). Evidence of improving yield and morphological attributes via halfsib family recurrent selection in maize. American J Exp Agric 3(3): 557-570.

21. Sohail A, Rahman H, Hussain Q, Hadi F, Khan W, Khan MA, Asad M, Yousafzai Z, Sami $\mathrm{S}$ \& Uddin S (2018). Improvement in CIMMYT maize population CZP-132011 through recurrent selection using half-sib families. ARPN J Agric Boil Sci 11(9): $1-6$.

22. Sajjad M, Khan NU, Rahman HU, Khan K, Hassan G, Gul S, Ali S, Afridi K, Ali I \& Khan SM (2016). Response of a maize composite to selfed progeny recurrent selection for earliness and yield traits. Maydica 34: 1-8. 